\title{
In the Name of Interculturality: On Colonial Legacies in Intercultural Education
}

\author{
Robert Aman
}

\section{Linköping University Post Print}

\section{Tweet}

N.B.: When citing this work, cite the original article.

Original Publication:

Robert Aman , In the Name of Interculturality: On Colonial Legacies in Intercultural Education, 2015, British Educational Research Journal, (41), 3, 520-534.

http://dx.doi.org/10.1002/berj.3153

Copyright: Wiley: 24 months

http://eu.wiley.com/WileyCDA/

Postprint available at: Linköping University Electronic Press

http://urn.kb.se/resolve?urn=urn:nbn:se:liu:diva-106243 


\title{
In the Name of Interculturality: On Colonial Legacies in Intercultural Education
}

\author{
Robert Aman \\ Linköping University
}

\begin{abstract}
This essay scrutinises the ways in which students who have completed a university course on interculturality distinguish between sameness and otherness in attempts to integrate, relate to, and build a bridge to those deemed culturally different. It makes use of interviews to analyse the factors that shape the interpretation of otherness and difference in the students' definitions of interculturality, as well as their statements about the relationships between us and them, and descriptions of instances of learning and teaching that have taken place between parties in different parts of the world. Theoretically, the essay is based on a postcolonial framework, highlighting the continuing influence of colonialism and Eurocentric ways of reasoning inside as well as outside the classroom in today's society. One of the main conclusions of the essay is that in the process of transferring knowledge, there is a risk that the history of modern Europe will be sanctioned as the historical trajectory for the rest of the world to follow, with the accompanying supposition that this can only be made possible by extending a helping hand to the Other.
\end{abstract}

Keywords: interculturality, intercultural education, multiculturalism, postcolonialism, eurocentrism

\section{Introduction}

The purpose of this essay is to discuss the construction of difference in the context of intercultural education, and to critically examine the ways in which the colonial legacy may influence how sameness is distinguished from otherness. Given that interculturality, by definition, demands the establishment of difference as a precondition to creating connections to otherness, this essay will resonate with the central argument of postcolonial theory that the effects of colonialism are still being felt today (cf. Mignolo, 2005; Young, 2004). Not least is this the case in contemporary educational practices and systems, where it has been argued that the colonial legacy is projected through desires, interests and ideas of what counts as knowledge (Appadurai, 2001). These assumptions about the ways in which Eurocentrism continues to form and sustain differences in inter-subjective relations inside as well as outside educational institutions have rarely been problematised in relation to the philosophy of education in general (cf. Rizvi et al., 2006), even less so in the field of intercultural education (Aman, 2013); a possible consequence of, researchers interested in this field implicitly assuming the value of interculturality, in which they are often themselves engaged as practitioners, and therefore being reluctant to propose any critiques of the concept in an attempt to justify, elucidate and legitimise its coherence (Chaudhuri, 2002).

Paying close attention to the details of policies on culture, the labour market or trade in the European Union, reveals the growing impact of interculturality as a strategy for dealing with otherness; but it is, above all, in education that the term has found a home. Instances of education are outlined as, to paraphrase UNESCO, fundamental pieces for construing interculturality and generating the skills necessary for a citizen in a society characterised by intercultural dialogue: 'Intercultural Education provides all learners with cultural knowledge, 
attitudes and skills that enable them to contribute to respect, understanding and solidarity among individuals, ethnic, social, cultural and religious groups and nations' (UNESCO, 2006, p. 37). The dividends of these policy formulations can arguably be seen in the rapid growth of interculturality as an educational subject in Europe (cf. Dahlén, 1997; Dewey, 2008), and in the way that calls for interculturality have become commonplace in educational rhetoric (Jones, 1999). Symptomatically, interculturality is now an educational theme at the vast majority of universities in the country at the centre of this case study: Sweden. ${ }^{1}$

In instrumentalising interculturality through education, or, rather, in viewing education as an instrument for interculturality, there is a tendency to read interculturality as a problem of knowledge; that is to say, interculturality is often framed in educational terms as what both we and they need to know in order to eradicate the borders between us (Aman, 2014a). According to the UNESCO outline above, intercultural education should equip its learners with the necessary skills and knowledge to bridge otherness, whereby interculturality also aims to be the dispenser of these required traits. Questions keep piling up; at the centre of this essay stands relation to otherness and difference; that is, into the grounds on which we establish us, and, simultaneously, them. It will also examine what is thought to constitute the 'right' kind of knowledge that should be taught and learnt in interculturality.

While previous studies on interculturality within the pedagogical sphere have focused on the structural level - theoretical elaborations (Walsh, 2005); policies (Aman, 2012); and curricula (Dunne, 2011) - my contribution in this essay is, through interviews with students who have completed one of these academic courses, to grapple with how people educated on interculturality use its language in order to bridge otherness by invoking that term. My approach is informed not only by the lack of critical interventions on interculturality (cf. Lentin 2005) but also by the fact that the distinction between sameness and otherness in Europe carries historical traces still burdened by colonialism. Throughout the exchange between Europeans and their Others that systematically began with the conquest of America, the one idea that remains intact, Edward Said (1993) argues, is that of difference - racial, ethnical or cultural - in constituting an $u s$ and a them, each quite settled, clear and selfevident.

The essay is organised as follows: I will begin by offering a succinct background to the concept of interculturality and its inescapable relationship with multiculturalism. After that, I will go on to present the postcolonial framework used in my analysis and the empirical material I draw upon. Thereafter the main findings will be presented. Finally, I will close by discussing the ways in which colonial structures may influence thinking about interculturality and be reproduced in the construction of difference.

\section{Enter Interculturality, Exit Multiculturalism}

Interculturality made its wider entrance into educational vocabulary in the early 1980s as the Council of Europe began to promote the word by specifically emphasising a dimension of reciprocity, which allegedly set it apart from the educational strategies of earlier decades in response to migration flows, such as Pédagogie d'accueil or Ausländerpädagogik (Portera, 2008). A key moment, according to Agostino Portera (2008), came when the European ministers of education unanimously passed a resolution for the schooling of migrant children in 1983, in which the importance of promoting interculturality was strongly underlined. Its journey from being a concept restricted to the teaching of immigrants to being propounded as the general pedagogical orientation towards the global multiculturalism of today is, among academic commentators, partly explained by the retreat of other educational strategies for knitting cultural scraps and patches into a social fabric. Primarily, the increased use of interculturality in, among other things, government policies and public debates about different 
forms of pluralism on both a supranational level (the EU, UNESCO, Council of Europe etc.) and within various national polities around Europe runs parallel with the diminished role of multiculturalism as an educational strategy for combatting exclusion and bridging otherness (Leeman, 2003).

Although multiculturalism remains much in use, it has been suggested that the lexical change from one prefix (multi) to another (inter) is the result of a conceptual confusion surrounding multiculturalism as the term has become a catch-all for a multitude of minority histories (Kymlicka, 1995). Others have argued that multiculturalism tends to fix and essentialise cultural and ethnic identities, rather than producing spaces where differences can be reconciled (cf. Dei, 1996; Eriksson, 2002; Sleeter \& Grant, 1987). Slavoj Žižek (1997, p. 44), in his critique of what he describes as the strategies of liberal tolerance underlying multiculturalism, goes so far as to provocatively draw parallels with the colonial endeavour, suggesting that each local culture is treated 'the way the coloniser treats colonised people - as "natives" whose mores are to be carefully studied and "respected"". Thus, among scholars, the majority view of interculturality and multiculturalism is clearly that the connotations of the terms are different; multiculturalism is seen to be a descriptive term for the factual coexistence of people of diverse cultures in a given space, whereas interculturality is said to characterise actual interaction between people, once impediments to relations have been removed (Camilleri, 1992; Gundara, 2000; Lahdenperä, 2004). Hence the positive connotations of the notion of interculturality are at war with the negative associations of the word multiculturalism. Or, as argued by academic commentators, where multiculturalism both begins and ends by making a diagnosis, intercultural education offers a cure: 'learning to live in an ethnically and culturally diverse society' (Leeman, 2003, p. 31).

However, critical voices have also been raised which point out the scant quantity of critical studies of interculturality (cf. Chaudhuri, 2002; James, 1999; Kymlicka, 2003). It has been argued that not only do studies of interculturality and intercultural education suffer from 'theoretical weakness' (Coulby, 2006, p. 254), but also that the overwhelming majority of work on intercultural education, "relies on "hunches" and attempts to do "good" (Gundara \& Portera, 2008, p. 465). Alana Lentin (2005) even suggests that multiculturalism and interculturality are different ways of talking about the same thing; that is, how to manage and integrate differences without ever attempting to problematise the underlying logics that distinguish one group from the other, whether such rationales take the name of race, ethnicity, culture or something else. Armed with this insight, my aim in the following essay is not to analyse the multifaceted approaches to interculturality and intercultural education or the ways in which the notion is being translated into practice. Such work on the apparent benefits of interculturality and how it is being employed in the classroom has been carried out in previous studies (cf. Cohen, 1994; Corbett, 2003; Crozet \& Liddicoat, 1999). The starting point for my interrogation is, rather, how students educated on interculturality describe and interpret the various process and relationships to otherness evoked by the notion.

\section{A Postcolonial Approach to Cultural Differences}

As noted above, the concept of difference plays a major part in the theoretical backdrop to this essay. On a superficial level, difference refers to the way in which one category (same) is distinguished from another (other). Without this comparative element, the interviewees' engagement with interculturality in other parts of the world would be restricted to little more than accounts of boarding flights or stepping off trains. While distinguishing one place or community from another may be inevitable, to make such a separation on the grounds of development is nonetheless never a neutral act. Based on a postcolonial approach, I will analyse the different criteria, conditions and elements mobilised in the informants' statements 
in order to describe and classify difference. This perspective draws attention to Eurocentric features, aligned to the Enlightenment, in their thinking about modernity, development and progress. In adopting such a critical idiom, a number of postcolonial scholars have shown that Europe, as an identity and culture, was formed in a dialectical relationship with a nonEuropean alterity. The colonial populations provided - and continue to provide - the mirror in which Europe could perceive itself as modern, enlightened and superior in contrast to an uncivilised, primitive and inferior Other (Bhabha, 1994; Mignolo, 2005; Spivak, 1985).

The construction of binary opposites in terms of modernisation, development and progress is an enduring feature of European civilisation and of a European history told from the perspective of Europe itself. From this point of view, Europe is not only the here and now (that is, the centre of space and the point of arrival in time) but also has the epistemic privilege of being the centre of enunciation in opposition to a contrasting image (Mignolo, 2002). According to Walter Mignolo (1999), to associate Africans, the indigenous populations of America, and other people on the fringes of the Western world with tradition, primitivism and emotionality was necessary in order to define modernity as the location in time of the ideals to be attained by humanity and to locate it in the geo-political space of Western Europe. As a consequence, Europeans have been able to self-ascribe themselves the task and obligation to educate, develop, and instruct their Others and their 'lesser' cultures. Not only is this chain of reasoning premised on a denial of co-evalness which conforms to and sustains a hierarchy of knowledge and knowers particularly adapted for colonialism, in which the most relevant distinction concerns one's cultural identity (Alcoff, 2007). It also has, it has been argued that a wider effect on the attributes and worth ascribed to individuals, on conceptions of knowledge, power and responsibility, and ideas regarding the origins of problems and the ways to go about solving them (Spivak, 2008).

A number of postcolonial scholars have highlighted that in dislocating other cultures spatially and temporally; that is, from the here and now, Europe, and later the West, have been able to represent their Others as existing on the same historical trajectory but further behind, to assert that we all share the same objectives but not everyone has achieved them to the same degree; and that our knowledge is subject to the same justificatory procedures and schemes, but others are less developed (Alcoff, 2007). Additionally, the assumption behind such categorisations of other cultures as existing in earlier stages of development is that we posses the attributes - knowledge, education, technology etc. - that they lack. Not only does such a perspective help reinforce the image of them as fundamentally different from $u s$, it may also legitimate the idea which Rudyard Kipling (1998[1899], p. 311) aptly formulated as 'the white man's burden'; that is, that we have a responsibility and obligation to help Others the way the white man had the burden of civilising and educating the non-European back in colonial times.

\section{Research Methodology}

As a basis for the analysis in this study, I draw upon empirical material comprised of fourteen interviews with students who have successfully completed a course on intercultural pedagogy $(30 \text { ECTS })^{2}$ at one of Sweden's major universities. According to its syllabus, studies in interculturality deals with cultural encounters with the purpose of 'broadening comprehension between people of diverse cultural backgrounds' and placing emphasis on the 'learning process in cultural meetings'. As part of the course's aims, the students are expected to acquire an intercultural perspective on 'cultural encounters in a globalised world' and the 'exchange of knowledge between cultures' and are trained in the ability to 'act in a concrete intercultural environment'. Moreover, the course at hand is described as outward-looking; the students are encouraged to study contexts and 'objects outside of Western majority culture 
and the multicultural environment in Sweden.' As will be displayed later in the analysis, the encouragement to take an interest in other cultures is close to the hearts of the students interviewed who all have either studied, worked or gone on long journeys in regions that, in the public imagination of the West, have long been described as underdeveloped and different (Said, 1993).

Scanning lists of students who had completed the course on interculturality during the last three years, I randomly interviewed fourteen of them. Five were males and nine were females, spanning the ages of 19 to 67, and all were Swedish citizens. To facilitate the process, I travelled to their current city of residence and let the interviewee decide on a preferred location for the interview to take place, in order for them to feel comfortable. This location varied between coffee shops, libraries, or even at their kitchen tables. To avoid rigid constructions in advance of the phenomena I aimed to study, the interviews were semistructured (Kvale, 2007) - conducted individually, tape-recorded and later transcribed - and were designed as a space to facilitate dialogue about the concept of 'interculturality' and to invite them to reflect on the ways they could approach and, in addition, bridge otherness by invoking that term. As is the aim of the qualitative interview, the focus is not on quantifying the interviewees' statements, rather emphasis is placed on grasping the ambiguity, and the sometimes contradictory, chains of logic, in the respondents' enunciations (Kvale, 2007).

As I do not believe in the existence of an objective external world, I am not particularly concerned with the truthfulness of the informants' accounts. Rather my understanding of the research interview is informed by Tim Rapley's (2004, p. 26) assertion that the qualitative interview is not about establishing the truth of respondents' experiences, actions, and feelings, but rather 'how specific (and sometimes contradictory) truths are produced, sustained and negotiated'. From this point of view, it is also important to emphasise that the interview is a construction site of knowledge, where the interviewer, to a certain degree, is an accomplice to the respondent in the knowledge-producing process (Kvale, 2007). Such an approach acknowledges that the transcribed interview text is as much a product of the social dynamic that was at play between myself and the respondents as an accurate reflection of the questions asked and the answers given. In short, knowledge produced in the interview is a joint construction in and through interaction between the researcher and the respondent, where the insights gained, to a large extent, depend on the relationship established between the parties involved.

In accordance with a theoretically informed methodology, I will critically examine the underlying lines of thought and assumptions discerned in the interviewees' statements on otherness and difference, teaching and learning, in the name of interculturality. The analysis of the material has been guided by the following questions: what type of knowledge is being mobilised through interculturality? What characteristics are ascribed to sameness vis-à-vis otherness? In this context, how are binaries, such as modern/traditional, reason/emotion, or culture/nature, construed? The results of the analysis are presented together with a number of examples (translated from Swedish) illustrating central patterns and lines of thought in the material.

\section{The Bridge Over: Defining Interculturality}

If the literature presented above characterises interculturality in relation to multiculturalism, the same thing can be said about the students interviewed. Highly visible throughout the material is the desire among the informants to disseminate an understanding of what separates interculturality from multiculturalism. Thus, wherever interculturality is primarily used it is employed distinctively from multiculturalism: the latter is suggested to be a term that 
describes the existence of cultural diversity in a space, whereas the former is said to emphasise actual interaction between cultures. Here are Maja's thoughts on the matter:

\begin{abstract}
Maja: It's [multiculturalism] like us versus them. I feel like it's more about establishing a fact. It only says that there are many cultures but it does not show that there's some kind of interaction. It's a dead word. Interculturality demands perhaps more. It requires that you give a little bit more of yourself, to open oneself. You don't have to do that if you conclude that we live in a country with many cultures.[...] I think that it's extremely antiquated to talk about multiculturalism, only as a term that says this is how it is. Interculturality is a good concept that describes something more and it's there that we have to arrive if we 're to get away from the antagonism that exists in society.
\end{abstract}

In line with presentations of interculturality in many other domains where it has gained momentum - from policy writings to curricula and scholarship - its particular appeal seems to derive from an emphasis on interaction, on approaching the Other, engaging with the Other. For Maja, to speak of interculturality in place of multiculturalism seems to be a step forward, it signals a certain readiness to consider other ways of being, pointing towards a future without the antagonism that she argues is prevalent in today's Sweden. Living together, rather than merely side by side, seems to be what separates interculturality from multiculturalism. Hence the positive connotations of the notion of interculturality are at war with the negative associations of the word multiculturalism. This line of reasoning is further developed by another interviewee, Emil, who emphasises mutual interaction between parties.

Emil: It [interculturality] means cultural meeting. Cultures that meet and blend, that perhaps together create a new culture. One picks the different pieces and perhaps we form a new kind of culture. One lets the cultures of both sides, or ways of being or whatever it may be as one defines a culture live on. It's not like one tries to shove down one of them, rather one tries to live on but together and then maybe we create a new culture jointly. This is what I feel to be intercultural, the meeting point.

In this understanding of cultural alterity, otherness is inscribed into the possibility of different ways of being; it seems possible to argue that interculturality is an act of approaching the Other and attempting to bridge the gap from that position. For Emil, it is thus important to underline that interculturality, as an encounter between cultures, needs to be characterised by a relationship that is both horizontal and mutual. Accordingly, it seems fair to say that hierarchies are incompatible with interculturality, especially since the interviewee is careful to point out that interculturality has the potential to open up a space to form new cultures jointly of the bits and pieces from all the cultures present. Left unclear, however, is the possibility of hybrid cultures whose paradoxical makeup cuts across the binaries of - among other unified entities - national belonging. In this line of reasoning, there is, of course, a certain risk that cultures will not be seen as already diverse, hybrid, and lived processes. Their call, urgent and necessary as it may be, to stitch the multicultural threads of the present into a larger garment in the name of interculturality, has the potential to reinforce the idea of cultures as reified things, since such a stance relies on the assumption of separate and distinct cultures.

Moving from definitions to contextual circumstances, in relation to the question of how otherness is interpreted, the interviews provide a distinction between the 'West' and the 'Third World', the latter also referred to as the 'Global South'. A common theme among the interviewees is the added experience of having resided, worked, studied or done extensive traveling in either Latin America or Africa (with the exception of two students who referred to experiences in the Middle East in a similar manner). This demonstrates, on the one hand, economic privileges which have enabled them to travel the world; on the other hand, all of the interviewees acknowledged a dedication to global issues and eagerness to learn about other cultures in other parts of the world as a primary reason for enrolling in the course, an interest that varied between a longstanding devotion and newly sparked enthusiasm. Irrespective of 
the sources of the individual subjects' interest in interculturality, the interviews revealed that acquired experiences become the surface against which the students brace themselves in readings of otherness. To further elucidate the ways in which sameness vis-à-vis otherness is determined through interculturality, I will now direct my attention towards the factors that categorise the Other as Other.

\section{Back to your Roots: Exoticism as Critique of Civilisation}

The students' interest in interculturality initially appears to be marked by fascination with remote territories and personal travelogues, experiences that - as will be discussed later serve as platforms for exploring intercultural relations. This impression is further established by the topics of their written course papers, such as 'Craftsmanship in Nicaragua', 'Living conditions for the indigenous people in Bolivia' and 'Perceptions of democracy in Guatemala'. One informant comments on his and other students' choice of subjects: 'I come from Landskrona and I think about how little I know about Landskrona. It's so embarrassing! I know like ten times more about Cochabamba. I could write about the construction of Landskrona football stadium, how it has affected the local population. However, then I think, what would I do that for?'

This is not a unique way of reasoning: for all of the informants, it is their experience living in the Global South that has furnished them with the examples which they draw upon in determining the conditions of otherness. Nevertheless, statements are not limited to the context they refer to; it is through readings of otherness that the interviewees come to see the contingencies in their own scheme of things. Another student, Greta, gives a personal reflection from Peru on the ways in which cultural encounters made her grapple with the cultural values that she acquired in Sweden, which have made her reason in a specific manner and approach things in a certain way.

Greta: So when I come to another culture as in Peru where it is very different from how it is in Sweden, then I am confronted with this and it becomes an exchange between the people one learns to know. But I also think it is about questioning your own cultural values and things like that. After all, the things that I consider to be right are very subjective, and have to do with the place where I grew up and what is considered right and wrong [there].

Although emphasis is continuously placed on a dichotomised relationship understood in terms of national cultures, Greta invokes another component to interculturality: the ability to reflect oneself in the Other, to mirror one's own ways of being and knowing through alterity. In demonstrating how subjectivity is articulated in relation to ideas and culturally conditioned values, Greta is acknowledging that there are many ways of knowing and many knowers throughout the world. In other words, interculturality can be seen as a way of learning about oneself as much as learning about Others. Another example of this double hermeneutic is Ingrid who refers to life in Kenya in response to the question of whether she could give an example of an intercultural experience.

Ingrid: When I was there, it was more or less like going back to the 1950s. In the store, there was a clerk who weighed your vegetables when you put them in a bag, there were a lot of people to ask if you had an inquiry, meaning there were a lot of people working there. At the bus, that was privately owned, there were always two who worked - one who drove and one who collected the money. It was like this in Sweden once upon a time, but it is not anymore. [...] Here you come into a store and there's no one to ask, you find nobody. Is this something to strive for? Is it better than the 1950s? To me it is not. They see it [Europe] as some kind of mechanical marvel, for them Europe is really special. But I do not know.

In this passage, Ingrid narrates a testimony of an evolutionary journey that separates the two 
spaces - on the one hand, Sweden and Europe; on the other hand, Kenya and Africa. Positioned in time, the two appear as indivisible entities; Africa is turned into an empirical foundation from which to internally criticise the dismal effects and social costs of postindustrialisation and modernity in Europe. She argues that the Kenya of today resembles the Sweden of the 1950s, which she explains was a society characterised by more human interactions, care and social security. This society was far from the sterile, mechanical and contemporary climate to which she had grown accustomed. Emphatically, the student seeks to problematise a discourse of modernisation as something to strive for, to show how the costs may exceed the benefits, by placing emphasis on the darker side of modernity, here graspable through the allegorical reading of a store empty of human presence. By reading time in space, certain traces of what has vanished from the here and now of the contemporary West are identified in a subtle manoeuvre as still existent and alive in other parts of the world. While there even seems to be a bit of comfort in people living like we used to do, Said (1978) affirms that romantic pictures of other regions are inseparable from a critique of the European present. At the same time, the different ways in which subjects relate to modernity and its effects become not only markers of difference between spaces and regions, but also the informants' own location in time and space. The inability to explain the world without measurements of progress serving as society's central code designate the subject who is subsumed in a history modelled on modern Europe as the one who can make such affirmations.

While these assertions may be regarded as attempts to problematise beliefs that ideas of modernisation and progress are necessarily always something to aim for, they also reveal what Said (1978) has referred to as 'positional superiority'; that is, the power, inherited from colonialism, to survey and judge spaces in geo-social comparison, the privilege to able to affirm that 'they' see Europe as something 'really special' and believe it to be a modern wonder. From this point of view, positional superiority allows for the recognition that there is a downside to modernity; a certain type of knowledge possibly reserved for those who are part of modernity. Not only are such statements essentially aligned with the belief that we - as individuals and collectives - know better than them, but it also turns particular contexts into objects against which advancement can be measured through a linear view of history. In the case of these quotations, these affirmations help reinforce the image of African soils and inhabitants as fundamentally different from the West. As will become evident in the next section, this line of reasoning has consequences for what can be taught and learned in encounters with otherness.

\section{Bridging the Gap: Translating Otherness}

In the above narratives about journeys into the African or Latin American continents, the travelling subject - the interviewee - seems to have crossed the frontier of modernity. While it appears fair to say that the students express ambivalent sentiments about certain effects of modernity, the use of the notion, however, gives rise to an outside, or conversely, an inside that belongs to another time or stage of development. Given the emphasis on learning in intercultural discourse, this would then imply that learning would need to cross both time and space.

Among some of the informants, however, there is an awareness of the pitfalls of translating across frontiers, which is most explicitly articulated by Kristina. Providing an example from difficulties that arose in the classroom during her volunteer work in Mexico, she stresses that,

I used concepts such as democracy, the words 'to organise' and 'social movement' in Spanish. And if you ask someone 'what is democracy to you?' an eleven year old may answer that it makes people kill other people - 
they've had a civil war there. Thus, that's not a good word when you want to attract people in the countryside. Social movement? Well, that's the guerrillas and that was something negative and if one allied oneself with the guerrillas one could get killed by the military. And if you got organised, those were the first doors that they came knocking on at night to take you outside to kill. So those three words I thought were great and important, they meant quite the opposite there. [...] This was very instructive to me. Very instructive.

In this quotation, the student clearly illustrates the problem of transferring concepts not only over linguistic lines but also to another socio-political context. Consequently, she was faced with the problem that certain key words and ideas that she aimed to teach lost their validity due to the fact that historical and political circumstances in Mexico have attached a completely different connotation to the words. While the interviewee shows great awareness of how meaning is shaped by context, aspects that limit, or at least complicate, interculturality, it still does not seem make her negotiate her own subject position. Rather the focus remains on the teaching of 'democracy', 'social movement' and 'ways to organise', where it seems plausible to argue that the student attempts to solve the problem by saying the same thing using different concepts not sustained by the lived realities of those she aims to teach. Although most of the descriptions of the exchange between the Swedish students and their designated Others seem to be based on the assumption that they know something that Others might benefit from, it is repeatedly emphasised that hierarchies ought to be avoided. In the following excerpt, for instance, Karl describes his contribution to knowledge in an intercultural practice:

Karl: Efficiency, to do several things at the same time. Time is valuable. It is a big conflict with time. It is like that with the cultural aspects, that they clash of course. Efficiency is one of those key aspects that one seeks to help out with, to seize time. Otherwise nothing happens, one does not get anywhere. [...] It's complicated things. But efficiency and... but then power structures and corruption also emerge. It's such a big part of everything I think. But compound knowledge and simple bookkeeping... stuff like that, and then there's the struggle against time since one has different perspectives on it. I'm not saying that it's wrong or anything like that, but that it's different.

Discernible in the informant's account is the idea of a specific level to which Latin Americans ought to ascend by becoming efficient. And the only way of arriving there, or as it is phrased in the excerpt, for something to happen to get somewhere, is to learn a certain ability to parenthesise a capricious relationship to time. Thus, they have a problem identified by $u s$, one might say, to which we have the solution. Among postcolonial scholars, ways of reasoning based on ideas of development and progress have been increasingly criticised for being both simplified and Eurocentric (cf. Jonsson, 2009; Mignolo, 1999). The linear notion of modernisation is based on the idea that it is the historical development of Europe that forms the ideal model for understanding historical progress as a whole. By turning Europe into a universal yardstick, an illusion is created that Europe and, as in the quotation above, parts of Latin America exist in two completely different worlds and eras.

However, it must be acknowledged that the students express hesitation about such educational efforts by admitting that ideas based on assumptions that we know better than them are always problematic. These ambivalent sentiments are brought to a point when an interviewee stresses that they probably could acquire the desired knowledge on their own, before adding that the task is therefore to give them a helping hand, to ensure they reach the right path. While insisting on all our sameness by underlining that we all have the same capacity to learn, this very ability of the Other is not fully trusted by holding on the need to supervise them and to assist them.

The idea that they can follow our path in the development of efficiency, in learning how to manage time, is based on another assumption. It presupposes that there exists among those who are educated on interculturality some kind of inherited knowledge, which it is possible to 
teach, of how clock-centric logic will enable them to modernise. Not only do such statements construct binary opposites by ascribing Europeans the position of progressive agents of the future (those who give), while turning Others into passive representatives of the past (those who receive). One might say that the polarisation is clear and untroubled: it is us (the developed) versus them (the underdeveloped), but the tendency to transfer notions of development and efficiency to other contexts also dismisses the idea of knowledge as sensitive to cultural differences. What the excerpts demonstrate is not only how the privilege of universalising derives from the dominant position ascribed to Europe through imperialism, seen as the order everyone ought to strive to imitate, as has been argued by postcolonial scholars (cf. Mignolo, 2005), but also the severe difficulties of thinking outside of a European framework (Aman, 2014b).

While the focus here has predominantly been on what the students consider to be their own contribution to an intercultural dialogue, it ought to be remembered that all the students emphasise that they have an explicit ambition to also learn from the Other. Several informants suggest that interculturality is a way for them to learn new perspectives, to see things in a different light. A concrete example is provided by Lennart, who describes the ways in which viewpoints may alter when referring to life in Ecuador:

Lennart: We grow up, in some ways, to be more individualistic than one is raised to be in Ecuador and South America - there's another way of thinking about it [there]. [...] It becomes, in some way, more concrete there where poverty and misery come much closer to you which also makes you think of what's important in life. In fact, everyone ought to do a trip like this at some point. Meet those poor children in the street who're three years old and play guitar to scramble for some money. Somewhere one needs maybe to torture oneself to understand what is important. [...] So I think that it's good even though it's hard to see it. Their exchange to us is more on the human side and ours more concrete knowledge.

A consistent remark from the interviewees is that time is structured differently depending on locality. Thus, time is a factor that draws a boundary between sameness and otherness. This is not to suggest, however, that different ways of structuring time are regarded as negative for all the informants. Quite the opposite: several of the students depict a less time-orientated environment as desirable, mentioning how it makes them feel relaxed and comfortable. It is also such statements that illustrate the ambivalent nature of the students' statements as time also stands out as the significant factor against which educational interventions are to be made. In this quotation, it is possible to detect how the use of we aligns itself with certain assets, which contrast with South Americans, in general, and Ecuadorians, in particular, and their imagined qualities and characteristics. Similarly to Sophie's previous account of our alienation from ourselves, the privileged and strictly organised Swedes, or modern Westerners, are here contrasted with Ecuadorians whose hardships of life in terms of poverty and misery are represented in a positive way.

In this chain of logic of associating Ecuadorians with collectivism and warmth, emotional abilities that the informant refers to as part of the 'human side', the picture emerging is of the natural and spontaneous Latin Americans contrasted with the more enlightened part of the world's population with which the informant identifies, those who carry within themselves 'concrete knowledge'. This resembles the kind of exotic fantasy that several postcolonial theorists have drawn attention to: Frantz Fanon ([1952]2008, p. 108) writes that ' $[\mathrm{w}]$ hen the Whites feel they have become too mechanised they turn to the Coloreds and request a little human sustenance'. Conversely, exposure to poverty, in the economic vernacular, is alleged to be of therapeutic benefit for the privileged eyes of the Western spectator, giving one an ability both to testify about life in the Global South and, simultaneously, contemplate one's own privileges. Difference in this account assents to a logic in which a lack of material resources, paradoxically, also becomes a virtue. 


\section{Concluding Remarks}

With postcolonial theory as my point of departure, I have analysed the ways in which students who have completed a course on interculturality distinguish between sameness and otherness. In several respects, the analysis points towards a contradictory picture. The ways in which interculturality is being defined, the relationships between the different parties, and the instances of learning and teaching that take place between them described in the material clearly show, on the one hand, that there is a strong emphasis on horizontal relationships, on moving forward together, and learning from each other. On the other hand, differences influenced by the colonial legacy appear in descriptions of the Other, visible in the ways that space and time are mobilised to distinguish between here and there, now and then (measurements of development: modern versus backward), and in what the informants consider to be their contribution vis-à-vis that of the Other in an intercultural dialogue ('concrete knowledge' versus 'human warmth'). Against this background, it seems possible to argue that interculturality for the students interviewed is a way to pass on knowledge and share experiences of how to modernise, while those designated as Others are restricted to offering a human touch. Not only does such transference of knowledge, paradoxically, reject meaning shaped by context, it also risks erasing the complexity of the histories, lives and struggles of the Other. In short, the Other is deemed to occupy the same space but assigned to a different time.

Although the informants acknowledge a principal benefit of interculturality to be gaining new perspectives, their case sensitiveness to other geo-political contexts does not seem to be to such a degree that it prevents a universalization of their own epistemic credentials. From this viewpoint, the history of modern Europe becomes sanctioned as a historical trajectory for the rest of the world to follow, with the accompanying supposition that this can only be made possible by extending a helping hand to the Other (Kapoor, 2004). With the colonial archive as with interculturality, any attempt to turn the other into a self has to come to terms with the fact that the project of colonialism was to do the very same thing, refracting "what might have been the absolutely Other into a domesticated Other that consolidates the imperialist self' (Spivak, 1985, p. 253).

However, this background of the continuously intertwined histories of the world as a legacy of colonialism also begs the question whether it is even possible at all to avoid reproducing colonialist cartographies when locating the Other in the Global South. Exchanges between the 'First' and 'Third World', whether they are economic, political or cultural, can seemingly never be immune to the global hierarchies still marked by a colonial past. Not limited to intercultural education alone, postcolonial theorists have pointed out that Eurocentrism and cultural supremacy have produced a sense among Westerners, inside as well as outside educational settings, that they live in the centre of the world, have a responsibility to help others, and that 'people from other parts of the world are not fully global' (Spivak, 2008, p. 23). Such colonial echoes in Western strivings toward global solidarity have been uncovered in, among others, popular education (Nordvall \& Dahlstedt, 2011), international education (Hughes, 2009), and feminist movements (Mohanty, 2003).

This is not to suggest, however, that interculturality is condemned to failure and should therefore be abandoned. The postcolonial approach deployed in this essay is an important instrument for capturing the ways in which Eurocentrism continues to inform ways of knowing and thinking. Nevertheless, I have only focused here on one, albeit important, aspect of a complex problem involving interculturality. To further understand the significance of the ways in which the discourse of interculturality operates, additional knowledge is required in terms of research that includes a wider range of voices and perspectives, which will not only 
capture further nuances but may shed light on aspects omitted by the theories employed in this essay.

\section{Notes}

1. Through the academic year of 2010/11, the following Swedish universities gave at least one course on interculturality: Dalarna University, Göteborg University, Jönköping University, Karlstad University, Kristianstad University, Linköping University, Linnaeus University, Lund University, Malmö University, Mid Sweden University, Södertörn University, Umeå University, University West, and Uppsala University.

2. European Credit Transfer System. 30 ECTS equals one semester of full-time studies.

\section{Acknowledgements}

I am grateful to Andreas Fejes and Stefan Jonsson for their valuable and insightful amendments to previous drafts of this essay.

\section{Notes on Contributor}

Robert Aman is a PhD student at Linköping University, Sweden. A former Visiting Fellow with the Program in Literature at Duke University and at the Faculty of English Language and Literature at the University of Oxford, his dissertation, Impossible Interculturality?: Education and the Colonial Difference in a Multicultural World, was recently published by Linköping University Press. He is a founding editor of the peer-reviewed and interdisciplinary journal, Confero: Essays on Education, Philosophy \& Politics.

\section{References}

Alcoff, L. (2007) Mignolo's Epistemology of Coloniality, CR: The New Centennial Review, 7(3), 79-101.

Aman, R. (2012) The EU and the Recycling of Colonialism: The Formation of Europeans Through Intercultural Dialogue, Educational Philosophy and Theory, 44(9), 1010-1023.

Aman, R. (2013) Bridging the Gap to Those Who Lack: Intercultural Education in the Light of Modernity and the Shadow of Coloniality, Pedagogy, Culture \& Society, 21(2), 279-297.

Aman, R. (2014a) Impossible Interculturality?: Education and the Colonial Difference in a Multicultural World (Linköping, Linköping University Press).

Aman. R. (2014b) Why interculturalidad is not interculturality: Colonial Remains and Paradoxes in Translation between Supranational Bodies and Indigenous Social Movements, Cultural Studies, 1-24. 10.1080/09502386.2014.899379

Appadurai, A. (2001) Globalization (Durham, Duke University Press).

Bhabha, H. (1994) The Location of Culture (London, Routledge).

Camilleri, C. (1992) From multicultural to intercultural: How to move from one to the other, In: J. Lynch, C. Modgil, \& S. Modgil, Cultural diversity and the schools (London, Falmer Press).

Chaudhuri, U. (2002) Beyond a 'Taxonomic Theater': Interculturalism after Postcolonialism and Globalization. The Drama Review, 32(1), 33-47.

Cohen, E. (1994) Designing Groupwork: Strategies for the Heterogeneous Classroom, (New York, Teachers College Press).

Coulby, D. (2006) Intercultural education: theory and practice, Intercultural Education, 17(3), 245-257.

Corbett, J. (2003) An intercultural approach to English language teaching (Clevedon, Multilingual Matters). 
Crozet, C. \& Liddicoat, A. J. (1999) The challenge of intercultural language teaching: Engaging with culture in the classroom, in: J. L. Bianco, A., J. Liddicoat \& C. Crozet (Eds.), Striving for the third place: Intercultural competence through language education (Melbourne, Language Australia).

Dahlén, T. (1997) Among the Interculturalists: An Emergent Profession and its Packaging of Knowledge (Stockholm, Gotab).

Dahlstedt, M., \& Nordvall, H. (2011) Paradoxes of Solidarity: Democracy and Colonial

Legacies in Swedish Popular Education, Adult Education Quarterly, 61(3), 244261.

Dei, G. S. (1996) Anti-racism education: theory and practice (Halifax, NS, Fernwood).

Dewey, P. (2008) Transnational Cultural Policymaking in the European Union, The Journal of Arts Managment, Law, and Society, 38(2), 99-118.

Dunne, C. (2011) Developing an intercultural curriculum within the context of the internationalization of higher education: terminology, typologies and power, Higher Education Research \& Development, 30(5), 609-622.

Eriksson, L. (2002) “Jag kommer aldrig att tillhöra det här samhället”: om invandrare, integration, folkhögskola (Linköping, Linköping University Press).

European Commission. (2007) Communication from the Commission: A European Agenda for Culture in a Globalizing World. Brussels, EC.

Fanon, F. (2008[1952]) Black Skin/White Masks (New York, Grove Press).

Gundara, J. (2000) Interculturalism, Education and Inclusion (London, Paul Chapman Publishing Ltd).

Gundara, J. \& Portera, A. (2008) Theoretical Reflections on Intercultural Education, Intercultural Education, 19(6), 463-468.

Hughes, C. (2009) International education and the International Baccalaureate Diploma

Programme, Journal of Research in International Education, 8(2), 123-141.

James, M. (1999) Critical Intercultual Dialogue. Polity, 31(4), 587-607.

Jones, A. (1999) The limits of Cross-Cultural Dialogue: Pedagogy, Desire

and Absolution in the Classroom, Educational Theory, 49(3), 299-316.

Jonsson, S. (2009) Rapport från Sopornas planet: kritiska essäer (Stockholm, Norstedt).

Kipling, R. (1998[1899]) The white man's burden, Peace Review, 10(3), 311-312.

Kvale, S. (2007) Doing interviews (Thousand Oaks, Calif., Sage Publications).

Kymlicka, W. (1995) Multicultural Citizenship (Oxford, Clarendon Press).

Kymlicka, W. (2003) Multicultural States and Intercultural Citizens, Theory and Research in Education, 1(2), 147-169.

Lahdenperä, P. (2004) Interkulturell pedagogik $i$ teori och praktik (Lund, Studentlitteratur).

Leeman, Y. (2003) 'School Leadership for Intercultural Education', Intercultural Education, 14 (1), 31-45.

Lentin, A. (2005) Replacing 'Race': Historicising the 'culture' in multiculturalism, Patterns of Prejudice, 39(4), 379-396.

Mohanty, C. T. (2003) Feminism without borders (Durham, Duke University Press).

Mignolo, W. (1999) Local histories/global designs: coloniality, subaltern knowledges, and border thinking (Princeton, Princeton University Press).

Mignolo, W. (2002) The Enduring Enchantment (or the Epistemic Privilege of Modernity and

Where to Go from Here), The South Atlantic Quarterly, 101(4), 927-954.

Mignolo, W. (2005) The idea of Latin America (Oxford, Blackwell Publishing).

Portera, A. (2008) Intercultural education in Europe: epistemological and semantic aspects, Intercultural Education, 19(6), 481-491.

Rapley, T. (2004) Interviews, In: C. Seale, G. Gobo, J. F. Gubrium \& D. Silverman (eds.) 
Qualitative Research Practice (London, Sage Publications).

Rizvi, F., Lingard, B., \& Lavia, J. (2006) Postcolonialism and education: negotiating a contested terrain, Pedagogy, Culture \& Society, 14(3), 249-262.

Said, E. (1978) Orientalism (London, Vintage).

Said, E. (1993) Culture and Imperialism (London, Vintage).

Sleeter, C. E., \& Grant, C. A. (1987) An analysis of multicultural education in the United States, Harvard Educational Review, 57(4), 421-444.

Spivak, G. C. (1985) Three Women's Texts and a Critique of Imperialism, Critical Inquiry, 12(1), 243-261.

Spivak, G. C. (2008) Other Asias (Oxford, Blackwell).

UNESCO (2006) Guidelines on Intercultural Education (Paris, UNESCO).

Young, R. (2004) White mythologies: writing history and the west (London, Routledge).

Walsh, C. (2005) Interculturalidad, conocimientos y decolonialidad, Signo y Pensamiento, 24(46), 39-50.

Žižek, S. (1997) Multiculturalism, Or, the Cultural Logic of Multinational Capitalism, New Left Review, 225, 28-51. 